\title{
Pengaruh Sektor Pariwisata Terhadap Pertumbuhan Ekonomi di Provinsi Kepulauan Riau Tahun 2011-2019
}

\author{
Spatial Regression data panel) \\ Farah Annisa $^{1 *}$, Cucu Sumarni ${ }^{2}$ \\ ${ }^{1,2}$ Politeknik Statistika STIS \\ Jalan Otto Iskandardinata No.64C, Jakarta Timur, 13330

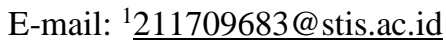

(The Impact of Tourism Sector on Economic Growth in Riau Islands Province in 2011-2019 Using

\begin{abstract}
ABSTRAK
Provinsi Kepulauan Riau (Kepri) acap kali dijadikan sebagai destinasi bagi wisatawan baik nusantara maupun mancanegara. Berdasarkan data BPS, total wisatawan yang datang ke provinsi ini cenderung naik setiap tahunnya. Namun, pertumbuhan ekonominya malah cenderung menurun. Hal ini disebabkan oleh sektor manufactur yang sampai dengan saat ini menjadi sektor andalan di provinsi ini, setiap tahunnya juga menurun. Untuk mengatasi hal tersebut perlu dicari sektor lain yang memiliki prospek. Oleh karena itu, penelitian ini bertujuan mengkaji pengaruh sektor pariwisata di Provinsi Kepulauan Riau terhadap pertumbuhan ekonominya dengan mempertimbangkan aspek spasial menggunakan regresi spasial data panel. Hasil penelitian memperlihatkan bahwa terdapat keterkaitan spasial antar wilayah/kabupaten di Kepri, artinya keberhasilan pembangunan yang dalam hal ini menggunakan pendekatan pertumbuhan ekonomi di suatu daerah berdampak pada daerah tetangganya. Selain itu, diperoleh bahwa Tingkat Penghunian Kamar (TPK) hotel non bintang di Kepri berpengaruh positif dan signifikan pada tingkat signifikansi 10 persen, sedangkan panjang jalan, banyaknya akomodasi, pajak daerah, dan retribusi tidak.
\end{abstract}

Kata kunci: Regresi spasial data panel, sektor pariwisata, Kepulauan Riau

\begin{abstract}
Riau Islands Province (Kepri) is often used as a destination for tourists both archipelago and foreign. Based on BPS data, the total number of tourists coming to this province tends to rise every year. But, economic growth tends to decline. This is due to the manufactur sector which until now became the leading sector in the province also decreased every year. To overcome this, it is necessary to look for other sectors that have prospects. Therefore, this study aims to examine the influence of the tourism sector in Riau Islands Province on its economic growth by considering spatial aspects using spatial panel regression. The results showed that there is a spatial linkage between regions / districts in Kepri, meaning that the success of development in this case using the approach of economic growth in an area has an impact on neighboring areas. In addition, it was obtained that the non-star hotel Occupancy Rate (TPK) had a positive and significant effect on 10 percent significance rate, while the length of the road, the number of accommodations, local taxes, and retributions are not.
\end{abstract}

Keywords: Spatial panel regression, tourism sector, Riau Islands

\section{PENDAHULUAN}

Kepulauan Riau (Kepri) merupakan salah satu provinsi di Indonesia yang acap kali dijadikan sebagai destinasi bagi wisatawan baik nusantara maupun mancanegara. Kepri memiliki wisata bahari hingga budaya yang menjadi daya tarik wisatawan dan menjadi salah satu provinsi dengan jumlah wisatawan mancanegara yang datang terbanyak di Indonesia serta menjadi provinsi dengan realisasi investasi pariwisata terbanyak kedua setelah Provinsi Bali (Cahya, 2019). Berdasarkan Gambar 1, dapat dilihat bahwa jumlah wisatawan yang datang ke provinsi ini cenderung mengalami peningkatan dari tahun ke tahun, yaitu tumbuh sekitar 12,43 persen pada tahun 2011 dan tumbuh sekitar 3,39 persen pada tahun 2012. Meskipun jumlah wisatawan yang datang ke Kepri mengalami penurunan pada tahun 2016 sebesar 5,74 persen, tetapi kembali meningkat pesat hingga mencapai 23,82 persen pada tahun 2018. Hal tersebut menunjukkan bahwa sektor pariwisata di Kepri berkembang dengan pesat.

Sayangnya, peningkatan kunjungan wisatawan ini tidak berbanding lurus dengan pertumbuhan ekonominya. Berdasarkan Gambar 1, pertumbuhan ekonomi Provinsi Kepri cenderung mengalami penurunan dari tahun ke tahun. Hal ini disebabkan sektor industri manufaktur yang memberikan peranan terbesar bagi perekonomian Kepri cenderung mengalami penurunan dari tahun ke tahun. Hal tersebut dapat disebabkan karena semakin berkurangnya sumber daya alam yang ada. 


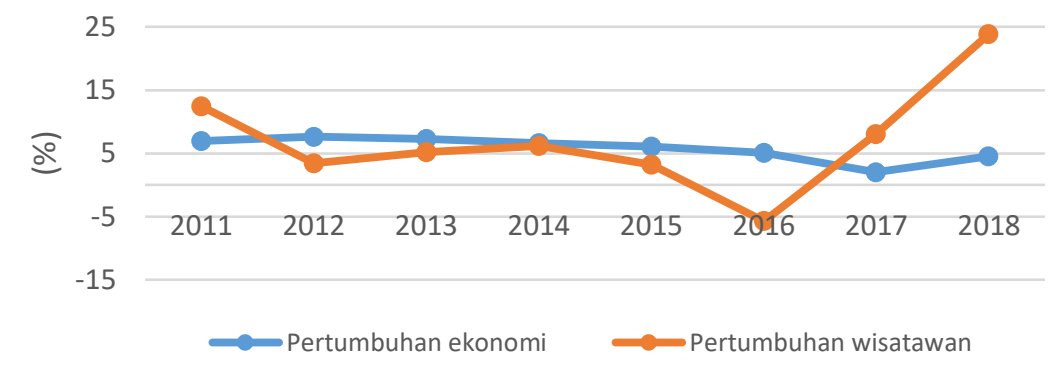

Sumber: Badan Pusat Statistik

Gambar 1. Pertumbuhan ekonomi dan pertumbuhan wisatawan mancanegara yang datang ke Provinsi Kepulauan Riau, 2011-2018

Berbeda halnya dengan sektor industri manufaktur yang cenderung mengalami penurunan setiap tahunnya, kontribusi sektor-sektor penyusun sektor pariwisata (Prastyo, 2018), seperti sektor penyediaan akomodasi dan makan minum, sektor transportasi, serta sektor informasi dan komunikasi cenderung mengalami peningkatan dari tahun ke tahun. Hal tersebut mengindikasikan bahwa sektor pariwisata diharapkan dapat menopang perekonomian Provinsi Kepri di masa yang akan datang. Oleh karena itu perlu dikaji hubungan sektor pariwisata terhadap perekonomian di provinsi tersebut.

Beberapa penelitian terkait hal itu telah dilakukan, diantaranya Amnar et al (2017) yang menunjukkan bahwa jumlah wisman, wisnus, lokasi wisata, dan Tingkat Penghunian Kamar (TPK) hotel berpengaruh positif dan signifikan terhadap pertumbuhan ekonomi di Kota Sabang, Nangro Aceh Darussalam. Marsus et al (2020) menunjukkan bahwa panjang jalan berpengaruh positif dan signifikan terhadap PDRB dan pertumbuhan ekonomi. Kurniasari (2020) menunjukkan bahwa pajak daerah berpengaruh positif dan signifikan terhadap pertumbuhan ekonomi daerah, namun retribusi daerah tidak berpengaruh terhadap pertumbuhan ekonomi daerah.

Selain itu, Budirahmayani dan Khoirunurrofik (2019) dengan menggunakan regresi spasial data panel menunjukkan bahwa terdapat spillover spasial pada pertumbuhan pariwisata di 33 provinsi. Spasial data panel digunakan untuk mengontrol hubungan dari waktu ke waktu, ruang dan antar unit penelitian. Bukan hanya mengetahui fixed effect, random effect, dan autokorelasi, tetapi juga memberikan keuntungan untuk mengontrol spillover spasial yang merupakan efek tumpahan suatu daerah ke daerah lainnya yang saling berdekatan (Kopczewska, Kudla, dan Walczyk, 2017). Daerah-daerah di Indonesia biasanya memiliki keterkaitan spasial karena wilayahnya yang saling berdekatan (Yanottama, 2018). Begitu juga dalam aspek ekonomi, biasanya terdapat keterkaitan antarwilayah yang berdekatan. Oleh karena itu, perlu dipertimbangkan adanya efek spasial dalam memodelkan dan mengestimasi indikator perekonomian.

Kepulauan Riau terdiri atas tujuh kabupaten/kota, di antaranya Kab. Bintan, Natuna, Karimun, Lingga, Kep. Anambas, Kota Batam, dan Tanjungpinang. Kepri memiliki 7 bandar udara dan 51 pelabuhan. Bandara Hang Nadim di Kota Batam merupakan bandar udara untuk akses nasional maupun internasional. Selain itu, pelabuhan-pelabuhan yang terdapat di setiap kabupaten/kota menjadi pintu masuk melalui jalur laut ke Kepri.
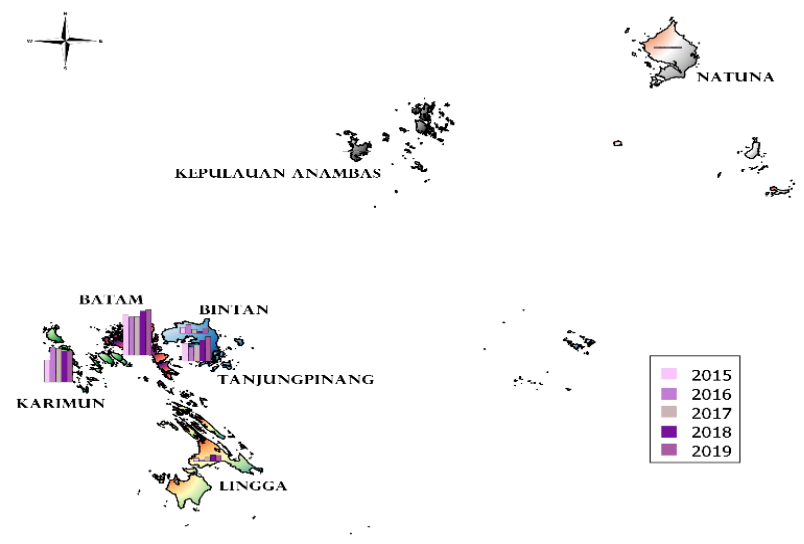

Sumber: BadanPusat Statistik

Gambar 2. Jumlah penumpang yang datang (jiwa), 2015-2019

Berdasarkan Gambar 2, dapat kita lihat bahwa jumlah penumpang yang datang melalui pelabuhan di Kepri cenderung mengalami peningkatan dari tahun ke tahun. Hal tersebut menunjukkan terdapat interaksi 
antar kabupaten/kota walau daerahnya saling terpisah. Selain itu, daerah yang berdekatan seperti Karimun, Batam, Tanjungpinang memiliki jumlah penumpang yang lebih tinggi dibandingkan kabupaten/kota lainnya dan menunjukkan adanya mobilitas yang tinggi antar kabupaten/kota. Berdasarkan penelitian Amriardi dan Buana (2019) diketahui bahwa terdapat kegiatan ekonomi antar kabupaten/kota melalui pelabuhan daerah masing-masing. Oleh karena itu, penelitian ini bertujuan untuk mengkaji pengaruh sektor pariwisata terhadap pertumbuhan ekonomi di Kepulauan Riau pada tahun 2011-2019 dengan mempertimbangkan efek spasial menggunakan regresi spasial data panel.

\section{METODE}

\section{Data dan Sumber Data}

Data yang digunakan di dalam penelitian ini adalah data sekunder yang bersumber dari Badan Pusat Statistik. Penelitian ini menggunakan data panel dengan unit observasi 7 kabupaten/kota di Kepri pada periode tahun 2011-2019. Variabel dependen yang digunakan dalam penelitian ini adalah pertumbuhan ekonomi. Variabel independennya antara lain Tingkat Penghunian Kamar (TPK) hotel, banyaknya akomodasi, panjang jalan, pajak daerah, dan retribusi. Adapun sumber dari variabel penelitian adalah sebagai berikut.

a. Data pertumbuhan ekonomi kab/kota di Provinsi Kepri diperoleh dari situs Badan Pusat Statistik $(2019 c)$.

b. Data TPK hotel diperoleh dari BPS (2011a,2012a,2013a, ..,2018a, dan 2019a). Penelitian ini menggunakan TPK hotel non bintang.

c. Data banyaknya akomodasi diperoleh dari BPS (2011a,2012a,2013a,2014a, ..., 2018a, dan 2019a). Penelitian ini menggunakan usaha akomodasi hotel berbintang dan hotel non bintang.

d. Data panjang jalan diperoleh dari BPS (2011a,2012a,2013a, ..., 2018a, dan 2019a). Namun dalam penelitian ini digunakan data persentase panjang jalan.

e. Data pajak daerah diperoleh dari BPS (2011b,2012b,2013b,2014b,2015b, .., 2018b, dan 2019b).

f. Data retribusi diperoleh dari BPS (2011b,2012b,2013b,2014b, .., 2018b, dan 2019b).

\section{Regresi Data Panel}

Data panel merupakan kumpulan data beberapa unit individual selama beberapa periode waktu. Regresi data panel memiliki tiga model (Baltagi, 2005) dengan oneway error antara lain sebagai berikut.

a. Common Effect Model/Pooled Model (CEM)

Model common effect mengasumsikan bahwa perilaku antar amatan sama dalam berbagai kurun waktu. Oleh karena itu, pada model ini nilai konstan $(\alpha)$ dianggap sama untuk semua cross section. Model persamaan CEM antara lain:

$\mathrm{Y}_{\text {it }}=\alpha+\mathbf{X}^{\prime}{ }_{\text {it }} \boldsymbol{\beta}+\varepsilon_{\text {it }} ; \mathrm{i}=1,2, \ldots, \mathrm{N}$ dan $\mathrm{t}=1,2, \ldots, \mathrm{T}$

Keterangan:

$\mathrm{Y}_{\mathrm{it}}=$ Variabel dependen unit ke-i pada waktu ke-t

$\alpha=$ Intersep dari persamaan (nilainya sama antar amatan)

$\mathrm{X}_{\mathrm{it}}=$ Variabel independen

$\beta=$ Koefisien parameter model

$\varepsilon_{\text {it }}=$ Error unit ke-i pada waktu ke-t

b. Fixed Effect Model (FEM)

Model fixed effect merupakan model yang berfokus pada satu set spesifik N. FEM mengasumsikan $\mu_{i}(\mathrm{i}=1,2, \ldots, \mathrm{N})$ bernilai tetap sehingga dapat diestimasi, $\varepsilon_{\mathrm{it}} \sim \operatorname{IID}\left(0, \sigma^{2}\right), \mathrm{E}\left(\mathrm{X}_{\mathrm{it}}, \varepsilon_{\mathrm{it}}\right)=0$, serta $\mathrm{X}_{\mathrm{it}}$ dan $\varepsilon_{\mathrm{it}}$ saling bebas untuk setiap i dan $\mathrm{t}$ (Baltagi, 2005). Adapun model persamaan FEM antara lain:

$\mathrm{Y}_{\mathrm{it}}=\alpha+\mu_{i}+\mathbf{X}_{\mathrm{it}}^{\prime} \boldsymbol{\beta}+\varepsilon_{\mathrm{it}} ; \mathrm{i}=1,2, \ldots, \mathrm{N}$ dan $\mathrm{t}=1,2, \ldots, \mathrm{T}$

Keterangan:

$\mu_{i}=$ Efek individu

c. Random Effect Model (REM)

Model random effect merupakan model yang menggunakan individu yang dipilih secara acak dari populasi yang besar $(\mathrm{N})$. Model ini mengasumsikan $\mu_{i} \sim \operatorname{IID}\left(0, \sigma_{\mu}{ }^{2}\right), \varepsilon_{\mathrm{it}} \sim \operatorname{IID}\left(0, \sigma^{2}\right), \mathrm{E}\left(\mathrm{X}_{\mathrm{it}}, \varepsilon_{\mathrm{it}}\right)=0$, serta $X_{\text {it }}$ dan $\varepsilon_{\text {it }}$ saling bebas (Baltagi, 2005). Model persamaan REM antara lain:

$\mathrm{Y}_{\mathrm{it}}=\boldsymbol{\alpha}+\mathbf{X}_{\mathrm{it}}^{\prime} \boldsymbol{\beta}+\mathrm{u}_{\mathrm{it}}$

$\mathrm{u}_{\mathrm{it}}=\mu_{\mathrm{i}}+\varepsilon_{\mathrm{it}} ; \mathrm{i}=1,2, \ldots, \mathrm{N}$ dan $\mathrm{t}=1,2, \ldots, \mathrm{T}$. 
Keterangan:

$\mathrm{u}_{\mathrm{it}}=$ Error ke-i pada waktu ke-t

\section{Regresi Spasial Data Panel}

Regresi spasial data panel merupakan regresi data panel yang mempertimbangkan efek spasial atau ketergantungan antarwilayah. Efek spasial antarwilayah tersebut dikuantifikasi dengan matriks penimbang spasial W. Terdapat dua model spasial dalam (Elhorst, 2014) antara lain:

1. Model Spatial Lag (SAR)

Model spatial lag merupakan model yang mengandung spatially lagged dependent variable atau keterkaitan spasial berkaitan dengan variabel dependennya. Spatial lag terjadi ketika nilai variabel dependen suatu wilayah berkorelasi dengan nilai variabel dependen wilayah tetangganya. Persamaan model spatial lag antara lain:

$y_{i t}=\alpha_{0}+\mu_{i}+\lambda \sum_{j=1}^{N} W_{i j} y_{j t}+\sum_{k=1}^{K} \beta_{k} X_{k i t}+\varepsilon_{i t}$

Keterangan:

$y_{i t}=$ Nilai variabel dependen amatan ke-i dan waktu ke-t

$\lambda=$ Koefisien autokorelasi spatial lag

$W_{i j}=$ Penimbang spasial

$y_{j t}=$ Nilai variabel dependen amatan ke-j dan waktu ke-t

$\beta_{k}=$ Parameter model ke-k

$X_{k i t}=$ Nilai variabel independen ke-k

$\mu_{i}=$ Efek individu

$\varepsilon_{i t}=$ Error observasi ke-i dan waktu ke-t

2. Model Spatial Error

Pada model spatial error, proses autoregresif spasial terdapat pada komponen error. Model ini menjelaskan keterkaitan spasial pada variabel lain yang belum tercakup dalam model atau yang termasuk di dalam error. Persamaan model spatial error antara lain:

$y_{i t}=\alpha_{0}+\mu_{i}+\sum_{k=1}^{K} \beta_{k} X_{k i t}+u_{i t}$

$u_{i t}=\rho \sum_{j=1}^{N} W_{i j} u_{j t}+\varepsilon_{i t}$

Keterangan:

$y_{i t}=$ Nilai variabel dependen

$\rho=$ Koefisien autokorelasi spatial error

$u_{j t}=$ Autokorelasi spatial error amatan ke-j dan waktu ke-t

\section{Uji Lagrange Multiplier}

Uji ini digunakan untuk mengetahui ada tidaknya efek keterkaitan spasial pada data. Adapun prosedur pengujiannya (Elhorst, 2014) antara lain sebagai berikut:

a. Uji LM spasial lag

Hipotesis:

$\mathrm{H}_{0}: \lambda=0$ (tidak terdapat autokorelasi spasial lag)

$\mathrm{H}_{1}: \lambda \neq 0$ (terdapat autokorelasi spasial lag)

Statistik uji:

$$
L M_{\lambda}=\frac{\left.\left[\mathbf{e}^{\prime}\left(\mathbf{I}_{\mathbf{T}} \otimes \mathbf{W}\right) \mathbf{Y} / \widehat{\sigma}^{2}\right)\right]^{2}}{J}
$$

dengan,

e $\quad=$ Vector sisaan (residual) model gabungan (pooled) tanpa adanya efek spasial

$\otimes \quad=$ Perkalian Kronecker

$\mathbf{I}_{\mathbf{T}} \quad=$ Matriks identitas berukuran TxT

$\mathbf{W}=$ Matriks penimbang spasial yang sudah dinormalisasi

$\widehat{\sigma}^{2}=$ Varians model gabungan (pooled) tanpa efek spasial

$\mathbf{I}_{\mathbf{N T}}=$ Matriks identitas berukuran NxT

tr $=$ trace matriks

Keputusan: Tolak $\mathrm{H}_{0}$ jika $\mathrm{LM}_{\lambda}>\chi^{2}{ }_{(p ; \alpha)}$, dimana $\mathrm{p}=1$ (banyaknya parameter spasial) atau memiliki $p$-value $<\alpha$ (tingkat signifikansi yang telah ditetapkan). 
b. Uji LM spasial error

Hipotesis:

$\mathrm{H}_{0}: \rho=0$ (tidak terdapat autokorelasi spasial error)

$\mathrm{H}_{1}: \rho \neq 0$ (terdapat autokorelasi spasial error)

Statistik uji:

$$
\mathrm{LM}_{\rho}=\frac{\left[\mathbf{e}^{\prime}\left(\mathbf{I}_{\mathrm{T}} \otimes \mathbf{W}\right) \mathbf{e} / \widehat{\sigma}^{2}\right]^{2}}{\mathrm{~T} \times \mathrm{T}_{\mathrm{W}}}
$$

c. Uji Robust LM spasial lag

Hipotesis:

$$
\begin{aligned}
& \mathrm{H}_{0}: \lambda=0 \\
& \mathrm{H}_{1}: \lambda \neq 0
\end{aligned}
$$

Statistik uji:

$$
\text { Robust } \mathrm{LM}_{\lambda}=\frac{\left.\left[\mathbf{e}^{\prime}\left(\mathbf{I}_{\mathbf{T}} \otimes \mathbf{W}\right) \mathbf{Y} / \widehat{\sigma}^{2}\right)-\mathbf{e}^{\prime}\left(\mathbf{I}_{\mathbf{T}} \otimes \mathbf{W}\right) \mathbf{e} / \widehat{\sigma}^{2}\right]^{2}}{\mathrm{~J}-\mathrm{TT}_{\mathrm{W}}}
$$

Keputusan: Tolak $\mathrm{H}_{0}$ jika Robust $\mathrm{LM}_{\lambda}>\chi_{(p ; \alpha)}^{2}$, dimana $\mathrm{p}=1$ (banyaknya parameter spasial) atau memiliki $p$-value $<\alpha$.

d. Uji Robust LM spasial error

Hipotesis:

$$
\begin{aligned}
& \mathrm{H}_{0}: \rho=0 \\
& \mathrm{H}_{1}: \rho \neq 0
\end{aligned}
$$

Statistik uji:

$$
\text { Robust LM } \mathrm{L}_{\rho}=\frac{\left.\left[\mathbf{e}^{\prime}\left(\mathbf{I}_{\mathbf{T}} \otimes \mathbf{W}\right) \mathbf{e} / \widehat{\sigma}^{2}-\mathrm{TT}_{\mathrm{W}} / \mathrm{J} \times \mathbf{e}^{\prime}\left(\mathbf{I}_{\mathbf{T}} \otimes \mathbf{W}\right) \mathbf{Y} / \widehat{\sigma}^{2}\right)\right]^{2}}{\mathrm{TT}_{\mathrm{W}}\left[1-\frac{\mathrm{TT}_{\mathrm{W}}}{\mathrm{J}}\right]}
$$

Adapun nilai $\mathrm{J}$ diperoleh dari:

$$
\begin{aligned}
& \mathbf{a}_{\mathbf{1}}=\left(\mathbf{I}_{\mathbf{T}} \otimes \mathbf{W}\right) \mathbf{X} \widehat{\boldsymbol{\beta}} \ldots \ldots \ldots \ldots \ldots . . . . . \\
& \mathbf{a}_{\mathbf{2}}=\mathbf{I}_{\mathbf{N T}}-\mathbf{X}\left(\mathbf{X}^{\prime} \mathbf{X}\right)^{-1} \mathbf{X}^{\prime} \ldots \ldots . \\
& \mathrm{J}=\frac{1}{\widehat{\sigma}^{2}}\left[\left(\mathbf{a}^{\prime}{ }_{1} \mathbf{a}_{\mathbf{2}} \mathbf{a}_{\mathbf{1}}\right)+\mathrm{TT}_{\mathrm{W}} \widehat{\mathrm{\sigma}}^{2}\right] \\
& \mathrm{T}_{\mathrm{W}}=\operatorname{tr}\left(\mathbf{W} \mathbf{W}+\mathbf{W}^{\prime} \mathbf{W}\right) \ldots \ldots \ldots
\end{aligned}
$$

\section{Uji Hausman}

Uji Hausman digunakan untuk menentukan efek model (fixed effect atau random effect) yang digunakan dengan melihat ada tidaknya korelasi antara variabel independen dan efek individu di dalam model. Berikut adalah tahapan untuk melakukan uji Hausman (Baltagi, 2005):

Hipotesis:

$\mathrm{H}_{0}: \mathrm{E}\left(u_{i t} / X_{i t}\right)=0$

$\mathrm{H}_{1}: \mathrm{E}\left(u_{i t} / X_{i t}\right) \neq 0$

Statistik uji:

$$
\begin{aligned}
& \chi^{2}{ }_{h i t}=\boldsymbol{d}^{\prime}[\operatorname{var}(\boldsymbol{d})]^{-1} \boldsymbol{d} \\
& \boldsymbol{d}=\widehat{\boldsymbol{\beta}}_{\boldsymbol{F E}}-\widehat{\boldsymbol{\beta}}_{\boldsymbol{R} E} \ldots \ldots \ldots \ldots \ldots \ldots \ldots \ldots \ldots \ldots \ldots \ldots \ldots \ldots \ldots \ldots \ldots \ldots \ldots \ldots \\
& \operatorname{var}(\boldsymbol{d})=\sigma^{2}{ }_{R E}\left(\boldsymbol{X}^{\prime} \boldsymbol{X}^{\prime}\right)^{-1}-\sigma_{F E}^{2}\left(\boldsymbol{X}^{*^{\prime}} \boldsymbol{X}^{*}\right)^{-1}
\end{aligned}
$$

Keputusan tolak $\mathrm{H}_{0}$, jika $\chi^{2}{ }_{\text {hit }}>\chi^{2}{ }_{(k)}(\mathrm{k}=\mathrm{jumlah}$ variabel independen dalam model, tidak termasuk intersep) atau nilai $p$-value $<(\alpha)$. Artinya, model fixed effect lebih tepat digunakan penelitian daripada model random effect.

\section{Uji Parsial}

Pengujian signifikansi parameter di dalam sebuah model yang digunakan dalam penelitian dapat menggunakan uji parsial T. Berikut tahapan untuk melakukan uji T dalam (Gujarati, 2004): Hipotesis:

$\mathrm{H}_{0}: \beta_{k} \leq 0 ;$ untuk $\mathrm{k}=1,2, \ldots, \mathrm{K}(\mathrm{k}=$ banyak variabel independen $)$

$\mathrm{H}_{1}: \beta_{k}>0$

Statistik uji:

$$
t_{\text {hit }}=\frac{\widehat{\beta}_{k}}{\operatorname{se}\left(\widehat{\beta}_{k}\right)}
$$


Jika nilai statistik uji $\mathrm{T}$ lebih besar dari nilai $t_{(\alpha ; n T-n-K)}$ atau nilai $p$-value kurang dari $(\alpha)$ maka keputusan tolak $\mathrm{H}_{0}$.

\section{Uji Kesesuaian Model (Goodness of Fit)}

Untuk mengetahui seberapa baik model yang sudah terbentuk atau kesesuaian model, maka dilakukan pengujian Koefisien Determinasi. Uji koefisien determinasi digunakan untuk melihat seberapa besar variabel independen dapat menjelaskan variabel dependen dalam model. Adapun rumus dari koefisien determinasi adalah sebagai berikut:

$$
R^{2}=\frac{S S R}{S S T}=1-\frac{S S E}{S S T}
$$

Jika nilai koefisien determinasi semakin besar, maka model yang terbentuk semakin baik, begitu pula sebaliknya.

\section{Metode Analisis Inferensia}

Analisis inferensia yang digunakan dalam penelitian ini adalah regresi spasial data panel menggunakan matriks penimbang spasial jarak (distance). Spesifikasi model spasial yang terbentuk secara umum adalah sebagai berikut.

$$
\begin{aligned}
& \text { PERT }_{i t}=\alpha_{0}+\mu_{\mathrm{i}}+\lambda \sum_{\mathrm{j}=1}^{7} \mathrm{w}_{\mathrm{ij}} \text { PERT }_{\mathrm{jt}}+\beta_{1} \text { TPK }_{\mathrm{it}}+\beta_{2} \mathrm{JALAN}_{\mathrm{it}}+\beta_{3} \text { AKOMODASI }_{\mathrm{it}}+\beta_{4} \mathrm{LN}\left(\mathrm{PAJAK}_{\mathrm{it}}+\right. \\
& \beta_{5} \mathrm{LN}(\mathrm{RET})_{\mathrm{it}}+\mathrm{u}_{\mathrm{it}} \\
& \mathrm{u}_{\mathrm{it}}=\rho \sum_{\mathrm{j}=1}^{7} \mathrm{w}_{\mathrm{ij}} \mathrm{u}_{\mathrm{jt}}+\varepsilon_{\mathrm{it}} \text {. }
\end{aligned}
$$

Keterangan:

PERT $_{\text {it }} \quad:$ Pertumbuhan ekonomi kabupaten/kota ke-i tahun ke-t

TPK $_{\text {it }} \quad$ : Tingkat Penghunian Kamar hotel non bintang

AKOMODASI $\mathrm{it}_{\mathrm{it}}$ : Banyaknya akomodasi hotel

JALAN $_{\text {it }} \quad$ : Persentase panjang jalan

LN(PAJAK) : Pertumbuhan pajak

LN(RET) $)_{\text {it }} \quad$ : Pertumbuhan retribusi

Adapun tahapan analisis regresi spasial data panel dalam (Anselin, 1988) adalah sebagai berikut:

1. Menguji keterkaitan spasial dan model yang terbentuk menggunakan uji Lagrange Multiplier (LM spasial lag atau LM spasial error).

2. Memeriksa hasil pengujian Lagrange Multiplier ((LM spatial lag atau LM spatial error), jika:

a. Kedua uji tidak signifikan, maka dapat disimpulkan model yang terpilih adalah regresi data panel karena tidak terdapat keterkaitan spasial.

b. Salah satu uji signifikan, maka dapat disimpulkan model tersebut digunakan pada tahapan selanjutnya.

c. Jika kedua uji signifikan, maka dilakukan pengujian Robust Lagrange Multiplier.

3. Apabila hasil pengujian menunjukkan bahwa kedua uji Lagrange Multiplier signifikan, maka periksa hasil uji Robust Lagrange Multiplier, jika:

a. Uji Robust Lagrange Multiplier Lag memiliki nilai signifikan yang lebih keci1, maka model yang terpilih adalah model spasial lag (SAR).

b. Uji Robust Lagrange Multiplier Error memiliki nilai signfikan yang lebih kecil, maka model yang dipilih adalah model spasial error (SEM).

4. Melakukan uji Hausman pada model yang terpilih untuk menentukan apakah model memiliki fixed effect atau random effect.

5. Melakukan estimasi model spasial panel.

6. Menguji kesesuaian model (Goodness of Fit).

7. Mengecek asumsi klasik.

8. Melakukan interpretasi dan analisis. 


\section{HASIL DAN PEMBAHASAN}

Langkah pertama dalam pembentukan model spasial adalah melakukan uji Lagrange Multiplier (LM) untuk mengetahui adanya efek spasial atau autokorelasi spasial. Jika hasil penelitian menunjukkan tidak terdapat efek spasial baik pada model autoregresi spasial maupun model galat spasial, maka pendekatan yang digunakan adalah regresi non-spasial. Jika didapatkan adanya efek spasial, maka pendekatan yang digunakan adalah regresi spasial. Hasil pengujian uji Lagrange Multiplier (LM) disajikan pada Tabel 1.

Tabel 1. Ringkasan Hasil Pengujian Lagrange Multiplier (LM)

\begin{tabular}{lccc}
\hline \multicolumn{1}{c}{ Uji LM } & Statistik Uji (LM) & df & p-value \\
\hline LM-lag & 10,544 & 1 & $0,001159^{*}$ \\
LM-error & 8,5442 & 1 & $0,003466^{*}$ \\
Robust LM-lag & 3,1352 & 1 & $0,07662^{*}$ \\
Robust LM-error & 1,1249 & 1 & 0,2889 \\
\hline
\end{tabular}

Keterangan: $*$ signifikansi taraf nyata 10\%

Tabel 1 memperlihatkan bahwa kedua uji LM spasial lag dan LM spasial error menghasilkan keputusan tolak $\mathrm{H}_{0}$ pada tingkat signifikansi 10 persen karena $p$-value yang diperoleh kurang dari 0,1 yang menunjukkan bahwa terdapat autokorelasi spasial baik spasial lag maupun spasial error. Selanjutnya dilakukan pengujian menggunakan Robust LM spasial lag dan Robust LM spasial error untuk memperoleh model yang lebih tepat.

Berdasarkan Tabel 1, pengujian Robust LM spatial lag menunjukkan keputusan tolak $\mathrm{H}_{0}$ pada tingkat signifikansi 10 persen. Oleh karena itu, spesifikasi model spasial yang paling tepat digunakan untuk mengetahui pengaruh sektor pariwisata terhadap pertumbuhan ekonomi di Kepri adalah model panel spasial lag (SAR).

Tahapan selanjutnya adalah melakukan estimasi parameter model spasial lag dengan fixed effect dan random effect. Dalam menentukan model yang terbaik akan digunakan uji Hausman. Pengujian menghasilkan keputusan tolak $\mathrm{H}_{0}$ karena nilai p-value yang diperoleh sebesar 0,0210 lebih kecil dari tingkat signifikansi 10 persen. Oleh karena itu, diperoleh kesimpulan bahwa model yang tepat digunakan dalam penelitian ini adalah model spasial lag dengan fixed effect. Berikut hasil estimasi parameter dari model yang terpilih.

Tabel 2. Ringkasan Hasil Estimasi Model

\begin{tabular}{lccc}
\hline \multicolumn{1}{c}{ Variabel } & Koefisien & Std. Error & t-stat \\
\hline Intercept & 24,995 & 10,184 & $2,4545^{*}$ \\
Spatial lag (lamda) & 0,406 & 0,12167 & $3,3381^{*}$ \\
TPK & 0,037 & 0,017858 & $2,0446^{*}$ \\
Jalan & $-0,011$ & 0,024717 & $-0,4323$ \\
Akomodasi & 0,066 & 0,073453 & 0,8950 \\
Ln(Pajak Daerah) & $-0,820$ & 0,519114 & $-1,5800$ \\
Ln(Retribusi) & $-0,605$ & 0,323927 & $-1,8672$ \\
\hline
\end{tabular}

Ket: $*$ signifikansi tarat nyata 10 persen; $t_{(0,1 ; 49)}=1,6753 ;$ - squared $=0,6751$

Setelah dilakukan pembentukan model, maka dilakukan pengecekan asumsi klasik, dan model tersebut telah memenuhi semua asumsi. Berdasarkan pengujian Kolmogorov-Smirnov, diperoleh statistik uji sebesar 0,1095 dengan nilai $p$-value 0,4073 . Artinya, dengan tingkat signifikansi 10 persen dapat diyakini bahwa $\mathrm{H}_{0}$ gagal ditolak, sehingga error berdistribusi normal. Selain itu, pengecekan asumsi multikolinearitas dengan menghitung nilai Variance Inflation Factor (VIF). Berdasarkan hasil pengecekan diperoleh nilai VIF masingmasing variabel sebesar TPK bernilai 1,2069; jalan bernilai 1,7269; akomodasi bernilai 2,7948; pajak bernilai 3,0989; dan retribusi bernilai 3,0148. Nilai VIF variabel-variabel tersebut kurang dari 10, sehingga disimpulkan bahwa tidak terdapat multikolinearitas antarvariabel.

Berdasarkan Tabel 2, terdapat satu variabel independen yang berpengaruh signifikan terhadap pertumbuhan ekonomi pada tingkat signifikansi 10 persen, yaitu Tingkat Penghunian Kamar (TPK) hotel. Sedangkan variabel lain seperti panjang jalan, banyaknya akomodasi, pajak daerah, dan retribusi daerah tidak berpengaruh signifikan terhadap pertumbuhan ekonomi. Selain itu, spatial lag signifikan pada tingkat signifikansi 10 persen dan berpengaruh positif terhadap pertumbuhan ekonomi. Spesifikasi model dapat ditulis dalam persamaan matematis sebagai berikut: 


$$
\begin{aligned}
\widehat{P E R T}_{i t}= & \left(24,995+\hat{\mu}_{i}\right)+0,406 \sum_{j=1}^{7} W_{i j} P E R T_{j t}+0,037 T P K_{i t}-0,011 \text { Jalan }_{i t}+ \\
& \text { 0,066Akomodasi } \\
i t & -0,820 \operatorname{Ln}\left(\text { Pajak }_{i t}-0,605 \operatorname{Ln}(\text { Ret })_{i t} ; \quad \mathrm{i}, \mathrm{j}=1,2, \ldots, 7\right.
\end{aligned}
$$

Tingkat Penghunian Kamar (TPK) hotel berpengaruh positif dan signifikan terhadap pertumbuhan ekonomi. Nilai slope sebesar 0,0365 menunjukkan bahwa jika TPK hotel meningkat sebesar 1 persen, maka akan meningkatkan pertumbuhan ekonomi sebesar 0,037 persen, dengan asumsi variabel-variabel lain bersifat konstan atau biasa disebut ceteris paribus. Hal tersebut sesuai dengan penelitian oleh Aneldus dan Dewi (2020) bahwa TPK hotel secara signifikan mempengaruhi pertumbuhan ekonomi di Kabupaten Manggarai Barat.

Kemudian, retribusi tidak berpengaruh signifikan terhadap pertumbuhan ekonomi kab/kota di Provinsi Kepri. Hal tersebut dapat disebabkan karena nilai retribusi kabupaten/kota di Kepri tidak bervariasi dan cenderung stagnan setiap tahunnya. Selain itu retribusi hanya didominasi oleh Kota Batam yang nilainya lebih tinggi dibanding kabupaten/kota lainnya, serta cenderung mengalami peningkatan dari tahun ke tahun. Berdasarkan penelitian Sunarto dan Sunyoto (2016), retribusi yang bernilai negatif disebabkan peraturan daerah terkait retribusi yang dapat menghambat para pelaku usaha, sehingga investor kurang tertarik untuk melakukan investasi. Padahal investasi memiliki peranan penting dalam pertumbuhan ekonomi.

Pajak daerah tidak mempengaruhi pertumbuhan ekonomi Kepri secara signifikan. Hal ini sejalan dengan penelitian oleh Saragih (2018) yang membuktikan bahwa peningkatan penerimaan pajak tidak selalu mengarah pada peningkatan pertumbuhan ekonomi. Hal ini dapat disebabkan oleh pajak daerah yang digunakan untuk membiayai pengeluaran yang tidak produktif. Jika pajak daerah digunakan untuk membiayai kegiatan atau proyek produktif, maka dapat berdampak positif terhadap pertumbuhan ekonomi suatu wilayah atau negara. Selain itu, pajak daerah yang diperoleh antar kabupaten/kota juga cukup jauh berbeda, terutama di Kota Batam yang memiliki pajak daerah lebih tinggi dibanding kabupaten/kota lainnya.

Selanjutnya, panjang jalan tidak berpengaruh secara signifikan terhadap pertumbuhan ekonomi di Kepri. Penelitian oleh Handayani, Susetyo, dan Saleh (2017) memperlihatkan bahwa panjang jalan berpengaruh negatif terhadap PDRB. Selain itu, hal tersebut juga disebabkan oleh terdapat beberapa kabupaten yang bisa diakses hanya melalui jalur udara dan laut, sehingga mengurangi minat wisatawan untuk berkunjung ke daerah tersebut. Sehingga perlu dilakukannya pemerataan pembangunan infrastruktur guna meningkatkan minat wisatawan.

Lalu, banyaknya akomodasi tidak signifikan berpengaruh terhadap pertumbuhan ekonomi di Kepri. Banyaknya akomodasi tidak signifikan mempengaruhi pertumbuhan ekonomi di Kepulauan Riau dapat terjadi karena akomodasi hotel di kabupaten/kota masih belum merata. Berdasarkan BPS, kita dapat melihat bahwa akomodasi hotel didominasi oleh Kota Batam, sedangkan kabupaten/kota lainnya tidak begitu signfikan.

Nilai koefisien spatial lag yang signifikan menunjukkan bahwa terdapat keterkaitan pertumbuhan ekonomi antarwilayah, artinya pertumbuhan ekonomi suatu wilayah dipengaruhi oleh pertumbuhan ekonomi wilayah-wilayah di sekitarnya. Nilai koefisien yang positif juga menunjukkan bahwa terdapat pengelompokkan wilayah berdasarkan pertumbuhan ekonominya. Koefisien spasial dari lag pertumbuhan ekonomi sebesar 0,406 menunjukkan bahwa jika suatu wilayah tetangga secara rata-rata mengalami pertumbuhan ekonomi sebesar 1 persen, maka akan mendorong pertumbuhan ekonomi wilayah tersebut sebesar 0,406 persen.

Berdasarkan data BPS, rata-rata pertumbuhan ekonomi kabupaten/kota yang saling berdekatan, seperti Kota Batam, Kab. Karimun, Kab. Bintan, Kota Tanjungpinang, dan Kab. Lingga berkisar antara 4,5 persen hingga 6,2 persen setiap tahunnya. Selain itu, ketika pertumbuhan ekonomi Batam mengalami penurunan, maka pertumbuhan ekonomi kabupaten/kota di sekitarnya juga mengalami penurunan, begitupula sebaliknya. Hal ini menunjukkan adanya keterkaitan spasial antardaerah tersebut. Selain itu, berdasarkan Gambar 2, dapat dilihat bahwa terdapat mobilitas antardaerah yang dapat meningkatkan pertumbuhan ekonomi. Hal ini sejalan dengan penelitian Takdir (2020) yang menunjukkan bahwa mobilitas penduduk dapat meningkatkan pertumbuhan ekonomi suatu daerah.

Pemodelan regresi data panel dengan fixed effect memiliki efek individu yang melekat pada setiap unit observasi spasial. Efek individu $\mu_{i}$ menunjukkan bahwa terdapat karakteristik suatu wilayah yang tidak tercakup di dalam model tetapi bepengaruh terhadap pertumbuhan ekonomi suatu wilayah. Efek individu tersebut menyebabkan terbentuknya pola-pola pada wilayah yang bersangkutan yang menggambarkan heterogenitas dari 7 unit observasi kabupaten/kota. Oleh karena itu, efek individu ini biasa dianggap sebagai keunggulan suatu wilayah dibandingkan wilayah sekitarnya.

Berdasarkan Tabel 3, efek individu terkecil berada di Kabupaten Kepulauan Anambas yaitu sebesar 6,5575 sedangkan efek individu terbesar berada di Kota Batam yaitu sebesar 5,8835. Sebagai contoh, analisis Kota Batam dengan tetangganya yaitu Karimun, Bintan, Lingga, Kepulauan Anambas, dan Kota Tanjungpinang dengan efek individu Kota Batam sebesar 5,8835. 
Tabel 3. Efek individu dari model

\begin{tabular}{lclc}
\hline \multicolumn{1}{c}{ Kabupaten/Kota } & Intersep & \multicolumn{1}{c}{ Kabupaten/Kota } & Intersep \\
\hline Karimun & 2.6874 & Kepulauan Anambas & -6.5575 \\
Bintan & 1.8907 & Batam & 5.8835 \\
Natuna & -3.0997 & Tanjungpinang & 1.0609 \\
Lingga & -1.8653 & & \\
\hline
\end{tabular}

Berikut adalah model spasial lag Kota Batam:

$$
\begin{aligned}
& \widehat{\text { PERT }}_{\text {Batam }, \mathrm{t}}=(30,8785)+0,0812 \mathrm{PERT}_{\text {Karimun }, \mathrm{t}}+0,0812 \mathrm{PERT}_{\text {Bintan }, \mathrm{t}}+0,0812 \mathrm{PERT}_{\text {Linggga }, \mathrm{t}}+ \\
& \text { 0,0812PERT } \text { Anambas }, \mathrm{t}+0,0812 \text { PERT }_{\text {Tjgpinang,t }}+0,037 \text { TPK }_{\text {Batam }, \mathrm{t}}-0,011 \mathrm{Jalan}_{\text {Batam }, \mathrm{t}}+ \\
& \text { 0,066Akomodasi } \text { Batam,t }-0,820 \operatorname{Ln}(\text { Pajak) })_{\text {Batam }, \mathrm{t}}-0,605 \operatorname{Ln}(\text { Ret })_{\text {Batam,t }} \text { …................. (24) }
\end{aligned}
$$

Berdasarkan Persamaan (24) dapat dilihat bahwa nilai pertumbuhan ekonomi Kota Batam sebesar 30,8785 persen jika tidak terdapat pengaruh dari daerah tetangga maupun pengaruh variabel-variabel independen. Selain itu, pada persamaan tersebut juga dapat dilihat bahwa setiap kenaikkan pertumbuhan ekonomi pada Kabupaten Karimun sebesar 1 persen maka pertumbuhan ekonomi Kota Batam akan meningkat sebesar 0,0812 persen dengan asumsi pengaruh Kabupaten Bintan, Kabupaten Lingga, Kabupaten Anambas, Kota Tanjungpinang, serta pengaruh variabel independen konstan. Peningkatan pertumbuhan ekonomi Kabupaten Karimun, Lingga, Kep. Anambas, dan Kota Tanjungpinang dapat meningkatkan pertumbuhan ekonomi Kota Batam karena adanya keterkaitan spasial antar wilayah tersebut.

\section{KESIMPULAN}

Berdasarkan hasil dan pembahasan diperoleh bahwa Tingkat Penghunian Kamar (TPK) hotel non bintang secara signifikan berpengaruh positif terhadap pertumbuhan ekonomi pada tingkat signifikansi 10 persen. Sedangkan variabel lain seperti panjang jalan, banyaknya akomodasi, pajak daerah, dan retribusi tidak berpengaruh signifikan terhadap pertumbuhan ekonomi di Kepulauan Riau.

Kemudian, koefisien spatial lag yang bernilai positif dan signifikan menunjukkan bahwa terdapat keterkaitan pertumbuhan ekonomi antarwilayah. Selain itu, diperoleh efek individu tertinggi pada Kota Batam dan terendah pada Kabupaten Kepulauan Anambas. Hal tersebut menunjukkan bahwa Kota Batam lebih unggul dibanding kabupaten/kota lainnya. Diharapkan sektor pariwisata di Kepulauan Riau terus diperbaiki dan dikembangkan agar menjadi sektor unggulan dan dapat meningkatkan pertumbuhan ekonomi Kepulauan Riau.

\section{DAFTAR PUSTAKA}

Amnar, S., Muhammad, S., \& Syechalad, M. N. (2017, Vol. 4(1)). Pengaruh Pariwisata Terhadap Pertumbuhan Ekonomi di Kota Sabang. Jurnal Ekonomi dan Kebijakan Publik Indonesia, 13-22.

Amriardi, U., \& Buana, I. S. (2019). Studi Keberlanjutan Layanan Angkutan Penyeberangan Wilayah Kepulauan (Studi Kasus Lintas Penyeberangan Kuala Tungkal-Dabo Singkep). Jurnal Wave, Vol. 13(2), 69-82.

Aneldus, S. Y., \& Dewi, M. H. (2020). Pengaruh Sektor-Sektor Pariwisata Terhadap Pendapatan Asli Daerah Dan Laju Pertumbuhan Ekonomi Kabupaten Manggarai Barat. E-Jurnal Ekonomi Pembangunan, Vol. 9(7), 1603-1630.

Anselin, L. (1988). Spatial Econometrics: Methods and Models. Dordrecht: Kluwer Academic Publishers. Baltagi. (2005). Econometric Analysis of Panel Data (3rd ed). England: John Wiley \& Sons, Ltd. BPS. (2011a). Kepulauan Riau Dalam Angka 2011. Jakarta: Badan Pusat Statistik. BPS. (2012a). Kepulauan Riau Dalam Angka 2012. Jakarta: Badan Pusat Statistik. BPS. (2013a). Kepulauan Riau Dalam Angka 2013. Jakarta: Badan Pusat Statistik. BPS. (2014a). Kepulauan Riau Dalam Angka 2014. Jakarta: Badan Pusat Statistik. BPS. (2015a). Kepulauan Riau Dalam Angka 2015. Jakarta: Badan Pusat Statistik. BPS. (2016a). Indikator Utama Kepulauan Riau Semester II 2016. Jakarta: Badan Pusat Statistik. BPS. (2017a). Indikator Utama Kepulauan Riau Semester II 2017. Jakarta: Badan Pusat Statistik. BPS. (2018a). Indikator Utama Kepulauan Riau Semester II 2018. Jakarta: Badan Pusat Statistik. BPS. (2019a). Indikator Utama Kepulauan Riau Semester II 2019. Jakarta: Badan Pusat Statistik. BPS. (2011b). Statistik Keuangan Pemerintah Kabupaten/Kota 2011-2012. Jakarta: Badan Pusat Statistik. BPS. (2012b). Statistik Keuangan Pemerintah Kabupaten/Kota 2012-2013. Jakarta: Badan Pusat Statistik. BPS. (2013b). Statistik Keuangan Pemerintah Kabupaten/Kota 2013-2014. Jakarta: Badan Pusat Statistik. 
BPS. (2014b). Statistik Keuangan Pemerintah Kabupaten/Kota 2014-2015. Jakarta: Badan Pusat Statistik. BPS. (2015b). Statistik Keuangan Pemerintah Kabupaten/Kota 2015-2016. Jakarta: Badan Pusat Statistik. BPS. (2016b). Statistik Keuangan Pemerintah Kabupaten/Kota 2016-2017. Jakarta: Badan Pusat Statistik. BPS. (2017b). Statistik Keuangan Pemerintah Kabupaten/Kota 2017-2018. Jakarta: Badan Pusat Statistik. BPS. (2018b). Statistik Keuangan Pemerintah Kabupaten/Kota 2018-2019. Jakarta: Badan Pusat Statistik. BPS. (2019b). Statistik Keuangan Pemerintah Kabupaten/Kota 2019-2020. Jakarta: Badan Pusat Statistik.

Badan Pusat Statistik. (2019). Pertumbuhan Ekonomi Tahunan-Persen, 2011-2019. Kepulauan Riau: Badan Pusat Statistik.

Budirahmayani, A., \& Khoirunurrofik. (2019). Tourism and Economic Growth: Spatial Perspective. Advances in Social Science, Education and Humanities Research (ASSEHR), Vol. 216 (pp. 7-24). Indonesia: Atlantis Press.

Cahya, K. D. (2019, Desember 6). Kontribusi Wisman Kepulauan Riau Kalahkan Jakarta. Kompas, p. 1.

Elhorst, J. P. (2014). Spatial Econometrics from Cross Sectional Data to Spatial Panels. New York: Springer.

Gujarati, D. N. (2004). Basic Econometrics (4th ed). Singapore: McGraw-Hill Inc.

Handayani, T., Susetyo, D., \& Saleh, M. S. (2017). Pengaruh Belanja Modal, Infrastruktur dan Indeks Pembangunan Manusia terhadap Produk Domestik Regional Bruto di Provinsi Sumatera Selatan. Jurnal Ekonomi Pembangunan, Vol. 15(2), 92-100.

Kopczewska, K., Kudla, J., \& Walczyk, K. (2017). Strategy of Spatial Panel Estimation: Spatial Spillovers Between Taxation and Economic Growth. Journal Spatial Analysis, Vol. 10, 77-102.

Prastyo, Yulian. (2018). Analisis Sektor Pariwisata Terhadap Pertumbuhan Ekonomi Provinsi Jawa Timur (Analisis Input-Output). Skripsi Universitas Jember. Jember.

Saragih, A. H. (2018). Pengaruh Penerimaan Pajak Terhadap Pertumbuhan Ekonomi di Indonesia. Jurnal Sistem Informasi, Keuangan, Auditting, dan Perpajakan, Vol. 3(1), 17-27.

Sunarto, \& Sunyoto, Y. (2016). Pengaruh Pajak Daerah dan Retribusi Daerah Terhadap Kemandirian Daerah yang Berdampak Pada Pertumbuhan Ekonomi Daerah (Studi Empiris pada Kabupaten dan Kota di Jawa Tengah. Jurnal Dharma Ekonomi, no.43, 13-22.

Takdir, M. Iqrar. (2020). Pengaruh Mobilitas Penduduk Dan Remitan Terhadap Pertumbuhan Ekonomi Di Kota Makassar. Skripsi Universitas Muhammadiyah Makassar. Makassar.

Yanottama, Ayub Hanan. (2018). Spatial Spillovers dan Pertumbuhan Ekonomi: Pendekatan Spatial Durbin Error Model Panel. Skripsi Universitas Muhammadiyah Semarang. Semarang. 